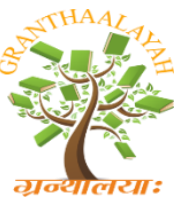

Science

\title{
THE PREDICTION OF THE THERMOHYDROGRAVIDYNAMIC THEORY CONCERNING THE STRONGEST INTENSIFICATIONS OF THE SEISMOTECTONIC AND CLIMATIC PROCESSES IN CALIFORNIA SINCE 9 AUGUST, 2017 AND BEFORE 3 MARCH, 2018
}

\author{
Dr. Sergey V. Simonenko *1 \\ ${ }^{* 1}$ V.I. Il'ichev Pacific Oceanological Institute, Far Eastern Branch of Russian Academy of \\ Sciences, Vladivostok, Russia
}

\begin{abstract}
The article presents (on October 12, 2017) the prediction (made on 9 August, 2017) of the established global prediction thermohydrogravidynamic principle (of the developed thermohydrogravidynamic theory based on the author's generalization of the first law of thermodynamics for non-stationary cosmic gravitation) concerning the strongest intensifications of the seismotectonic and climatic processes in California (since 9 August, 2017 and before 3 March, 2018) determined by the maximal (near 7 November, 2017) combined integral energy gravitational influence on the internal rigid core of the Earth (and on the Earth as a whole) of the planets (Mercury, Venus, Mars and Jupiter) and the Sun due to the gravitational interactions of the Sun with Jupiter Saturn, Uranus and Neptune. The prediction is based on the established global prediction thermohydrogravidynamic principle (used for the considered real planetary configurations of the Earth and the planets of the Solar System during the range 2004 - 2017) and on the statistical analysis of the previous strongest (according to the U.S. Geological Survey) earthquakes occurred in California near the calculated dates of the local maximal combined planetary and solar integral energy gravitational influences (during the range 2004 2016) on the internal rigid core of the Earth.
\end{abstract}

Keywords: Thermohydrogravidynamic Theory; Cosmic Geophysics; Cosmic Seismology; Generalized First Law of Thermodynamics; Non-Stationary Cosmic Gravitation; Natural Disasters in California; Numerical Modelling; Computer Technology.

Cite This Article: Dr. Sergey V. Simonenko. (2017). "THE PREDICTION OF THE THERMOHYDROGRAVIDYNAMIC THEORY CONCERNING THE STRONGEST INTENSIFICATIONS OF THE SEISMOTECTONIC AND CLIMATIC PROCESSES IN CALIFORNIA SINCE 9 AUGUST, 2017 AND BEFORE 3 MARCH, 2018." International Journal of Research - Granthaalayah, 5(10), 137-159.

\section{Introduction}

The prediction of the strongest seismotectonic [1-4], volcanic [4, 5] and climatic [4, 6, 7] processes of the Earth are the urgent problems [8-10] for humankind before the founded [9, 10] 
increased intensifications (during the forthcoming range $2020 \div 2026$ ) of the global natural (seismotectonic, volcanic, climatic and magnetic) processes [8-10] of the Earth.

We presented [11] the confirmed validity of the thermohydrogravidynamic theory [2-4, 7-12] of the global natural (seismotectonic, volcanic and climatic) processes concerning the strongest intensifications of the global natural processes of the Earth in 2016 since 1 September, 2016 and before 26 January, 2017. Analyzing (on 7 November, 2016, during the first correction of the article [11]) the climatic activity of the Earth in 2016, we concluded [11] that Hurricane Matthew produced the strongest devastating climatic (meteorological) activity during the predicted (in advance [12], on 31 August, 2016) range (19September $\div 23$ October, 2016) of the probable strongest (in 2016 since 1 September, 2016) intensification (characterized by the probability $\operatorname{Pr}=0.416$ ) of the global climatic (meteorological) activity of the Earth in 2016. According to the U.S. National Hurricane Center, Hurricane Matthew was (on 30 September, 2016) the most powerful devastating hurricane in the Atlantic since the last Category 5 Hurricane Felix observed in the Atlantic on September 2007. According to the U.S. National Hurricane Center, "Matthew's top sustained winds have risen from $115 \mathrm{mph}$ (185 kph) to $125 \mathrm{mph}$ (205 mph) in just a few hours early Thursday (on 6 October, 2016) as the storm continues to batter the central Bahamas" [13].

We pointed out [11] the unquestionable fact that the date of 6 October, 2016 (when "Hurricane Matthew has gained new muscle over the Bahamas" [13]) is in the perfect agreement with the calculated (in advance [12], on 31 August, 2016 based on the established [9-12] global prediction thermohydrogravidynamic principle (8)) numerical time moment $\mathrm{t}^{*}\left(\tau_{\mathrm{c}, \mathrm{r}}, 2016\right)=2016.7666$ (corresponding approximately to 6 October, 2016) of the maximal (in 2016) combined planetary and solar integral energy gravitational influence (8) on the internal rigid core $\tau_{\mathrm{c}, \mathrm{r}}$ of the Earth (and on the Earth as a whole). We pointed out [11] that the probability of this perfect agreement (considered as casual coincidence) is approximated by the obvious very small numerical value $(1 / 365) \cdot(1 / 365)$ confirming that this perfect agreement is not a casual coincidence. We concluded [11] that this perfect agreement may be considered as the convincing evidence of the validity of the established [9-12] global prediction thermohydrogravidynamic principle (8) concerning the maximal intensifications of the global and regional climatic activities of the Earth. We concluded [11] that this perfect agreement may be considered also as the convincing evidence of the cosmic (combined planetary and solar) energy gravitational genesis of the global and regional climatic (meteorological) activities of the Earth related with strong hurricanes.

We pointed out [11] the unquestionable fact that the strongest (in 2016 since 1 September and before 7 November, 2016) climatic (meteorological) activity of the Earth (related with Hurricane Matthew) corresponds perfectly to the predicted (in advance [12], on 31 August, 2016 based on the analysis of the previous strongest earthquakes during the range $(2004 \div 2015)$ ) range (19September $\div 23$ October, 2016) of the of probable strongest (in 2016 since 1 September, 2016) intensification (characterized by the probability $\operatorname{Pr}=0.416$ [11]) of the global climatic (meteorological) activity of the Earth. We considered [11] this unquestionable fact as the convincing evidence of the Gutenberg's [14] idea that the seismic activity of the Earth is closely related with the climatic (meteorological) activity of the Earth. 
We presented [11] the unquestionable facts (which confirm the Gutenberg's [14] idea about the global seismic-climatic relation) that the powerful (6.5-magnitude according to the Japan Meteorological Agency, 6.2-magnitude according to the U.S. Geological Survey) earthquake (occurred on 23 September, 2016 southeast of Tokyo and $143 \mathrm{~km}$ ESE of Katsuura according to the U.S. Geological Survey) and the powerful (6.6-magnitude according to the Japan Meteorological Agency, 6.2-magnitude according to the U.S. Geological Survey) earthquake (occurred on 21 October, 2016 in Tottori about 430 miles west of Tokyo and $6 \mathrm{~km} \mathrm{~S}$ of Kurayoshi according to the U.S. Geological Survey) were realized during the predicted (in advance [11], on 31 August, 2016) range (19September $\div 23$ October, 2016) of the probable strongest intensifications (characterized by the corresponding probability $\operatorname{Pr}=0.416$ [11]) of the global seismotectonic and climatic processes of the Earth in 2016 since 1 September, 2016.

Analyzing the seismotectonic activity of the Earth in 2016 since 9 December, 2016 (in addition to the made analysis [11]) and before 13 January, 2017 (by considering the significant earthquakes according to the U.S. Geological Survey), we established [15] the additional unquestionable facts (in addition to the considered facts [11]) that the powerful 7.9-magnitude earthquake (which struck the Papua New Guinea on 17 December, 2016) and the powerful 7.6magnitude earthquake (which struck the Chile on 25 December, 2016) belong to the predicted (in advance, on 7 November, 2016 [11]) range (28 June, 2016 $\div 13$ January, 2017) (characterized by the corresponding probability $\operatorname{Pr}=0.916$ of the strongest (in 2016) intensifications of the global seismotectonic and climatic processes of the Earth since 1 September, 2016), that confirms the reasonable applicability of the established [9-12] global prediction thermohydrogravidynamic principle for prediction of the global seismotectonic activity of the Earth in 2016. Analyzing the significant earthquakes of the Earth (according to the U.S. Geological Survey) since 9 December, 2016 and before 26 January, 2017 (which is the date of the publication [11]), we established [15] the additional unquestionable fact that the powerful 7.9-magnitude earthquake (which struck the Papua New Guinea on 22 January, 2017) belongs to the predicted (in advance, on 7 November, 2016 [11]) range (15 June, 2016 $\div 26$ January, 2017) (characterized by the corresponding probability $\operatorname{Pr}=0.99$ of the strongest intensifications of the global seismotectonic and climatic processes of the Earth since 1 September, 2016 and before 26 January, 2017), that confirms the reasonable applicability of the global prediction thermohydrogravidynamic principle (8) for prediction of the global seismotectonic activity of the Earth in 2016 and 2017. Analyzing the seismotectonic activity of the Earth in 2017 since 31 January, 2017 and before 10 April, 2017 (by considering the significant earthquakes according to the U.S. Geological Survey), we established [15] the additional unquestionable fact of the absence of the strong earthquakes (characterized by the magnitudes $M \geq 7.0$ ) in the range from 31 January, 2017 to 10 April, 2017, that confirms the reasonable applicability of the global prediction thermohydrogravidynamic principle (8) for prediction of the global seismotectonic activity of the Earth in 2016 and 2017.

The published (on August, 2017) prediction [15] of the established global prediction thermohydrogravidynamic principle (8) (of the developed thermohydrogravidynamic theory [24, 7-12, 15]) concerning the strongest intensifications (since $18 \mathrm{July,} 2017$ and before 26 February, 2018) of the global seismotectonic, volcanic, climatic and magnetic processes of the Earth is related with the maximal (near 7 November, 2017) combined integral energy gravitational influence on the internal rigid core of the Earth (and on the Earth as a whole) of the 
planets (Mercury, Venus, Mars and Jupiter) and the Sun (due to the gravitational interactions of the Sun with Jupiter Saturn, Uranus and Neptune). The prediction [15] is based on the established global prediction thermohydrogravidynamic principle (8) (used for the considered real planetary configurations of the Earth and the planets of the Solar System during the range $2004 \div 2017$ ) and on the statistical analysis of the previous strongest earthquakes occurred near the calculated dates of the local maximal combined planetary and solar integral energy gravitational influences (during the range $2004 \div 2017$ ) on the internal rigid core of the Earth. The considered (on 31 August, 2017 [15]) unquestionable fact ([16] published on August 27, 2017 that "damaging hurricane Harvey settles in over southeast Texas") confirms that the period of the damaging Hurricane Harvey belongs to the predicted (on 10 April, 2017 [15]) range (1 August, 2017 $\div 12$ February, 2018) characterized by the probability $\operatorname{Pr}=0.846$ [15] of the strongest intensifications of the global and regional natural processes of the Earth. The unquestionable fact ([17] published on 6 September, 2017 that "Hurricane Irma grew into a dangerous Category 5 storm, the most powerful seen in the Atlantic in over a decade, and roared toward islands in the northeast Caribbean Tuesday on a path that could eventually take it to the United States") confirms that the period of the Hurricane Irma intensification into a dangerous Category 5 storm belongs to the predicted (on 10 April, 2017 [15]) range (1 August, 2017 $\div 12$ February, 2018) characterized by the probability $\operatorname{Pr}=0.846$ [15] of the strongest intensifications of the global and regional natural processes of the Earth. We have the unquestionable fact that the strongest 8.1-magnitude (strongest in 2017 before 22 October, 2017 according to the U.S. Geological Survey) earthquake (which struck the Mexico on 8 September, 2017) belongs to the predicted (on 10 April, 2017 [15]) range (1 August, 2017 $\div 12$ February, 2018) (characterized by the probability $\operatorname{Pr}=0.846[15]$ ), that confirms also the validity of the global prediction thermohydrogravidynamic principle (8) (of the thermohydrogravidynamic theory $[2-4,7-12,15]$ ) concerning the second (in 2017) subrange of the strongest intensifications of the global natural (seismotectonic, volcanic, climatic and magnetic) processes of the Earth since 18 July, 2017 and before 26 February, 2018 near the calculated time moment $\mathrm{t}^{*}\left(\tau_{\mathrm{c}, \mathrm{r}}, 2017\right)=2017.85$ corresponding approximately to 7 November, 2017. The considered unquestionably related facts (about the strongest 8.1magnitude earthquake (which struck the Mexico on 8 September, 2017), the damaging Hurricane Harvey [16] and damaging Hurricane Irma [17]) confirm also the Gutenberg's [14] idea about the global seismic-climatic relation.

Taking into account the confirmed validity $[11,12,15]$ of the thermohydrogravidynamic theory [2-4, 7-12, 15] related with the considered unquestionable facts (about the strongest 8.1magnitude earthquake (which struck the Mexico on 8 September, 2017), the damaging Hurricane Harvey [16] and damaging Hurricane Irma [17]), we present (on October 22, 2017 to the International Journal of Research - Granthaalayah) the prediction (made on 9 August, 2017) of the thermohydrogravidynamic theory concerning the different forthcoming ranges (characterized by the calculated corresponding probabilities) of the strongest intensifications of the seismotectonic and climatic processes in California (since 9 August, 2017 and before 3 March, 2018) determined by the maximal (near 7 November, 2017) combined integral energy gravitational influence on the internal rigid core of the Earth (and on the Earth as a whole) of the planets (Mercury, Venus, Mars and Jupiter) and the Sun (due to the gravitational interactions of the Sun with Jupiter Saturn, Uranus and Neptune). 
In Section 2 we present the established generalized formulation (1) of the first law of thermodynamics [2-4, 7-12, 15, 18] for the symmetric stress tensor $\mathbf{T}$ [19] and the established [9-12] global prediction thermohydrogravidynamic principles (8) and (9) determining the maximal temporal intensifications of the global and regional natural (seismotectonic, volcanic, climatic and magnetic) processes of the Earth related with the maximal and minimal combined cosmic integral energy gravitational influences ((8) and (9), respectively, for the time moments $\mathrm{t}=\mathrm{t}^{*}\left(\tau_{\mathrm{c}, \mathrm{r}}\right)$ and $\mathrm{t}=\mathrm{t}_{*}\left(\tau_{\mathrm{c}, \mathrm{r}}\right)$ ) on the considered internal rigid core $\tau_{\mathrm{c}, \mathrm{r}}$ (of the Earth) subjected to the combined cosmic integral energy gravitational influence of the planets of the Solar System, the Moon and the Sun (owing to the gravitational interaction of the Sun with the outer large planets).

In Section 3 we present the prediction (based on the global prediction thermohydrogravidynamic principle (8) of the thermohydrogravidynamic theory [2-4, 7-12, 15] and based on the analysis of the significant (according to the U.S. Geological Survey) earthquakes (occurred since 2004 and before 2017) in California) concerning the strongest intensifications of the seismotectonic and climatic processes in California (since 9 August, 2017 and before 3 March, 2018) determined by the maximal (for the time moment $\mathrm{t}^{*}\left(\tau_{\mathrm{c}, \mathrm{r}}, 2017\right)=2017.85$, which corresponds approximately to 7 November, 2017) combined planetary and solar integral energy gravitational influences on the internal rigid core $\tau_{\mathrm{c}, \mathrm{r}}$ of the Earth.

In Section 4 we present (on 22 October, 2017) the confirmed validity (partially, for the range from 9 August, 2017 to 22 October, 2017) of the predicted (on 9 August, 2017 based on the established global prediction thermohydrogravidynamic principle (8)) probabilities (13) - (23) of the strongest intensifications of the seismotectonic and climatic (related with catastrophic wildfires in north California) processes in California during the predicted ranges (26) - (36).

In Section 5 we present the conclusions.

\section{Methodology}

Based on the general equation of continuum movement [19], the classical differential formulation [20] of the first law of thermodynamics for the one-component macrodifferential continuum element, the decomposition $\mathbf{P}=\mathrm{p} \boldsymbol{\delta}+\boldsymbol{\Pi}$ [20] for the pressure tensor $\mathbf{P}=-\mathbf{T}$ [19], the viscous-stress tensor $\boldsymbol{\Pi}$ [20] and the symmetric stress tensor $\mathbf{T}$ [19] ( $\boldsymbol{\delta}$ is the Kronecker delta-tensor, $\mathrm{p}$ is the thermodynamic pressure), we derived the generalized differential formulation (for individual finite continuum region $\tau$ considered in a Galilean frame of reference with respect to a Cartesian coordinate system $K$ shown on Fig. 1) of the first law of thermodynamics [2-4, 7-12]:

$$
\mathrm{dU}_{\tau}+\mathrm{dK}_{\tau}+\mathrm{d} \pi_{\tau}=\delta \mathrm{Q}+\delta \mathrm{A}_{\mathrm{np}, \partial \tau}+\mathrm{dG}
$$

where $\delta \mathrm{Q}$ is the classical [18-22] infinitesimal change of heat across the continuum boundary surface $\partial \tau$ of the continuum region $\tau, \mathrm{dU}_{\tau}$ is the classical [18-22] infinitesimal change of the internal thermal energy $U_{\tau}$ of the continuum region $\tau, \mathrm{dK}_{\tau}$ is the established [2-4, 7-12] infinitesimal increment of the macroscopic kinetic energy $K_{\tau}[18,23]$ of the continuum region 
$\tau, \quad d \pi_{\tau}$ is the established [2-4, 7-12] infinitesimal increment of the gravitational potential energy $\pi_{\tau}$ determined by the potential $\psi_{\text {comb }}$ of the combined (cosmic and terrestrial) nonstationary gravitational field, $\delta \mathrm{A}_{\mathrm{np}, \hat{\partial \tau}}$ is the generalized [2-4, 7-12] infinitesimal work done by non-potential terrestrial stress forces (characterized by the symmetric stress tensor $\mathbf{T}$ [19]) acting on the continuum boundary surface $\partial \tau$ of the continuum region $\tau$,

$$
\mathrm{dG}=\mathrm{dt} \iiint_{\tau} \frac{\partial \psi_{\text {comb }}}{\partial \mathrm{t}} \rho \mathrm{dV}
$$

is the established [2-4, 7-12] infinitesimal combined (cosmic and terrestrial) non-stationary energy gravitational influence on the continuum region $\tau$ during the time interval $\mathrm{dt}$. The relation (2) for $\mathrm{dG}$ takes into account the partial derivative $\partial \psi_{\text {comb }} / \partial \mathrm{t}$ of the potential $\psi_{\text {comb }}$ of the combined (cosmic and terrestrial) non-stationary gravitational field, the local mass density $\rho$ of the differential volume $\mathrm{dV}$ in the continuum region $\tau$.

The generalized differential formulation (1) of the first law of thermodynamics and the relation (2) result to the following relation:

$$
\mathrm{dG}=\mathrm{dt} \iiint_{\tau} \frac{\partial \psi_{\text {comb }}}{\partial \mathrm{t}} \rho \mathrm{dV}=-\mathrm{dt} \iint_{\partial \tau}\left(\mathbf{J}_{\mathrm{g}} \cdot \mathbf{n}\right) \mathrm{d} \Omega_{\mathbf{n}},
$$

which is the theoretical foundation [3, 4, 9-11] of the power $\mathbf{J}_{\mathrm{g}}$ of the gravitational energy (of the detected [1] non-relativistic classical "gravitational" waves [3, 4, 9, 10] propagating from the focal regions of earthquakes) across the surface element $\mathrm{d} \Omega_{\mathrm{n}}$ determined by the external normal unit vector $\mathbf{n}$. The theoretical foundation (3) is based on the relation [3, 4, 9-11] for the divergence $\operatorname{div} \mathbf{J}_{\mathrm{g}}$ :

$$
\operatorname{div} \mathbf{J}_{\mathrm{g}}=-\rho \frac{\partial \psi_{\text {comb }}}{\partial \mathrm{t}}
$$

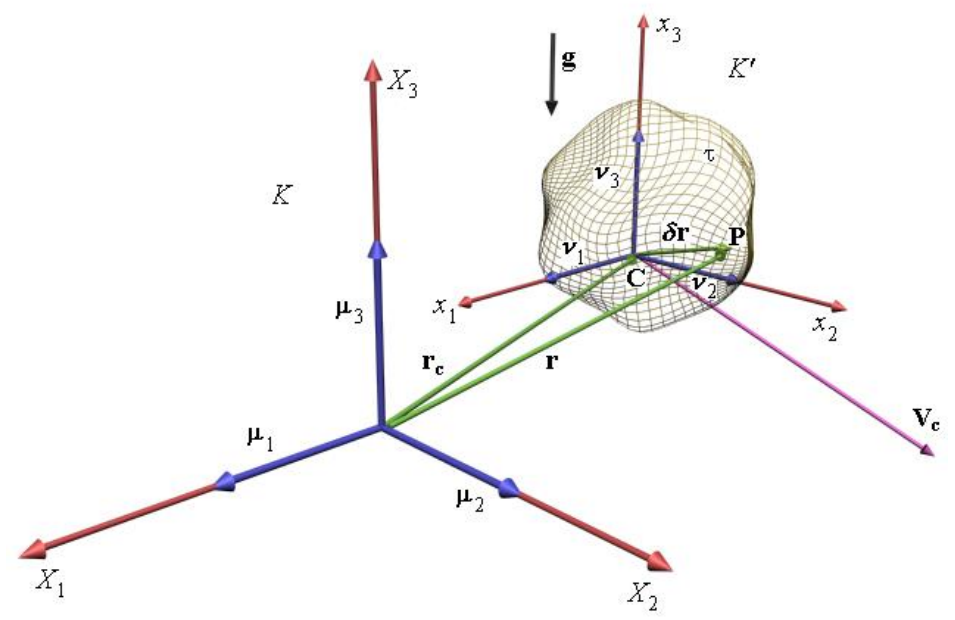

Figure 1: Cartesian coordinate system $K$ of a Galilean frame of reference and an individual finite continuum region $\tau$ subjected to the non-stationary combined (cosmic and terrestrial) Newtonian gravitation field and non-potential terrestrial stress forces 
We use the generalized differential formulation (1) of the first law of thermodynamics for the internal rigid core $\tau_{c, r}$ of the Earth (in the considered non-catastrophic model $[7,8]$ of the cosmic geology of the Earth characterized by the absence of the jump of the velocity field on the continuum boundary surface $\partial \tau_{\mathrm{c}, \mathrm{r}}$ between the internal rigid core $\tau_{\mathrm{c}, \mathrm{r}}$ and the fluid core $\tau_{\mathrm{c}, \mathrm{f}}$ of the Earth ):

$$
\mathrm{U}\left(\tau_{\mathrm{c}, \mathrm{r}}\right)+\mathrm{dK}\left(\tau_{\mathrm{c}, \mathrm{r}}\right)+\mathrm{d} \pi\left(\tau_{\mathrm{c}, \mathrm{r}}\right)=\delta \mathrm{Q}\left(\partial \tau_{\mathrm{c}, \mathrm{r}}\right)+\delta \mathrm{A}_{\mathrm{np}}\left(\partial \tau_{\mathrm{c}, \mathrm{r}}\right)+\mathrm{dG}\left(\partial \tau_{\mathrm{c}, \mathrm{r}}\right),
$$

where $\delta \mathrm{Q}\left(\tau_{\mathrm{c}, \mathrm{r}}\right)$ is the classical [18-22] infinitesimal change of heat across the continuum boundary surface $\partial \tau_{\mathrm{c}, \mathrm{r}}$ of the internal rigid core $\tau_{\mathrm{c}, \mathrm{r}}, \mathrm{dU}\left(\tau_{\mathrm{c}, \mathrm{r}}\right)$ is the classical [18-22] infinitesimal change of the internal thermal energy $\mathrm{U}\left(\tau_{\mathrm{c}, \mathrm{r}}\right)$ of the internal rigid core $\tau_{\mathrm{c}, \mathrm{r}}, \mathrm{dK}\left(\tau_{\mathrm{c}, \mathrm{r}}\right)$ is the established [2-4, 7-12] infinitesimal increment of the total macroscopic kinetic energy $\mathrm{K}\left(\tau_{\mathrm{c}, \mathrm{r}}\right)$ [18, 23] of the internal rigid core $\tau_{\mathrm{c}, \mathrm{r}}, \mathrm{d} \pi\left(\tau_{\mathrm{c}, \mathrm{r}}\right)$ is the established [2-4, 7-12] infinitesimal increment of the gravitational potential energy $\pi\left(\tau_{\mathrm{c}, \mathrm{r}}\right)$ (determined by the potential $\psi_{\text {comb }}$ of the combined cosmic and terrestrial non-stationary gravitational field) of the internal rigid core $\tau_{c, r}, \quad \delta A_{n p}\left(\partial \tau_{c, r}\right)$ is the generalized [2-4, 7-12] infinitesimal work done by nonpotential terrestrial stress forces (characterized by the symmetric stress tensor $\mathbf{T}$ [19]) acting on the continuum boundary surface $\partial \tau_{\mathrm{c}, \mathrm{r}}$ of the internal rigid core $\tau_{\mathrm{c}, \mathrm{r}}$,

$$
\mathrm{dG}\left(\tau_{\mathrm{c}, \mathrm{r}}\right)=\mathrm{dt} \iint_{\tau_{c, r}} \frac{\partial \psi_{\mathrm{comb}}\left(\tau_{\mathrm{c}, \mathrm{r}}\right)}{\partial \mathrm{t}} \rho\left(\tau_{\mathrm{c}, \mathrm{r}}\right) \mathrm{dV} \equiv \mathrm{dG}\left(\partial \tau_{\mathrm{c}, \mathrm{r}}\right)=-\mathrm{dt} \iint_{\partial \tau}\left(\mathbf{J}_{\mathrm{g}}\left(\partial \tau_{\mathrm{c}, \mathrm{r}}\right) \cdot \mathbf{n}\left(\partial \tau_{\mathrm{c}, \mathrm{r}}\right)\right) \mathrm{d} \Omega_{\mathbf{n}}\left(\partial \tau_{\mathrm{c}, \mathrm{r}}\right),
$$

is the established [2-4, 7-12] infinitesimal combined (cosmic and terrestrial) non-stationary energy gravitational influence on the internal rigid core $\tau_{c, r}$ during the time interval $\mathrm{dt}$. The relation (6) for $\mathrm{dG}\left(\tau_{\mathrm{c}, \mathrm{r}}\right) \equiv \mathrm{dG}\left(\partial \tau_{\mathrm{c}, \mathrm{r}}\right)$ takes into account the partial derivative $\frac{\partial \psi_{\mathrm{comb}}\left(\tau_{\mathrm{c}, \mathrm{r}}\right)}{\partial \mathrm{t}}$ of the potential $\psi_{\text {comb }}\left(\tau_{\mathrm{c}, \mathrm{r}}\right)$ of the combined (cosmic and terrestrial) non-stationary gravitational field in the internal rigid core $\tau_{c, r}$ of the Earth, the mass density $\rho\left(\tau_{c, r}\right)=12800 \mathrm{~kg} \cdot \mathrm{m}^{-3}$ [24] of the internal rigid core $\tau_{\mathrm{c}, \mathrm{r}}$, the power $\mathbf{J}_{\mathrm{g}}\left(\partial \tau_{\mathrm{c}, \mathrm{r}}\right)$ of the gravitational energy (of the non-relativistic classical "gravitational" waves [1] generated from the internal rigid core $\tau_{c, r}$ of the Earth) across the surface element $\mathrm{d} \Omega_{\mathrm{n}}\left(\partial \tau_{\mathrm{c}, \mathrm{r}}\right)$ (of the continuum boundary surface $\partial \tau_{\mathrm{c}, \mathrm{r}}$ ) determined by the external normal unit vector $\mathbf{n}$. The equality (identity) $\mathrm{dG}\left(\tau_{\mathrm{c}, \mathrm{r}}\right) \equiv \mathrm{dG}\left(\partial \tau_{\mathrm{c}, \mathrm{r}}\right)$ is based on the relation $[3,4,9-11]$ for the divergence $\operatorname{div} \mathbf{J}_{\mathrm{g}}$ :

$$
\operatorname{div} \mathbf{J}_{\mathrm{g}}\left(\partial \tau_{\mathrm{c}, \mathrm{r}}\right)=-\rho\left(\tau_{\mathrm{c}, \mathrm{r}}\right) \frac{\partial \psi_{\mathrm{comb}}\left(\tau_{\mathrm{c}, \mathrm{r}}\right)}{\partial \mathrm{t}}
$$

Based on the generalized formulation (1) of the first law of thermodynamics (used for the internal rigid core $\tau_{c, r}$ of the Earth), we formulated [9-12] the global prediction thermohydrogravidynamic principles determining the maximal temporal intensifications of the established [8, 10-12] thermohygrogravidynamic processes (in the internal rigid core $\tau_{c, r}$ and in 
the boundary region $\tau_{\mathrm{rf}}$ between the internal rigid core $\tau_{\mathrm{c}, \mathrm{r}}$ and the fluid core $\tau_{\mathrm{c}, \mathrm{f}}$ of the Earth) subjected to the combined cosmic energy gravitational influence of the planets of the Solar System, the Moon and the Sun (owing to the gravitational interaction of the Sun with the outer large planets). We concluded [8, 10-12] (based on the generalized formulation (1) of the first law of thermodynamics used for the internal rigid core $\tau_{c, r}$ of the Earth) that the maximal intensifications of the established thermohygrogravidynamic processes are related with the corresponding maximal intensifications of the global and regional natural (seismotectonic, volcanic, climatic and magnetic) processes of the Earth.

The rigorous global prediction thermohydrogravidynamic principles (determining the maximal temporal intensifications near the time moments $\mathrm{t}=\mathrm{t}^{*}\left(\tau_{\mathrm{c}, \mathrm{r}}\right)$ and $\mathrm{t}=\mathrm{t}_{*}\left(\tau_{\mathrm{c}, \mathrm{r}}\right)$, respectively, of the thermohydrogravidynamic processes in the internal rigid core $\tau_{\mathrm{c}, \mathrm{r}}$ and in the boundary region $\tau_{\mathrm{rf}}$ between the internal rigid core $\tau_{\mathrm{c}, \mathrm{r}}$ and the fluid core $\tau_{\mathrm{c}, \mathrm{f}}$ of the Earth) are formulated as follows $[8,10-12]$ :

$$
\Delta \mathrm{G}\left(\tau_{\mathrm{c}, \mathrm{r}}, \mathrm{t}^{*}\left(\tau_{\mathrm{c}, \mathrm{r}}\right)\right)=\max _{\mathrm{t}} \int_{\mathrm{t}_{0}}^{\mathrm{t}} \mathrm{dt}^{\prime} \iiint_{\tau_{\mathrm{c}, \mathrm{r}}} \frac{\partial \psi_{\text {comb }}}{\partial \mathrm{t}^{\prime}} \rho_{\mathrm{c}, \mathrm{r}} \mathrm{dV} \text { - local maximum for time moment } \mathrm{t}^{*}\left(\tau_{\mathrm{c}, \mathrm{r}}\right),
$$

and

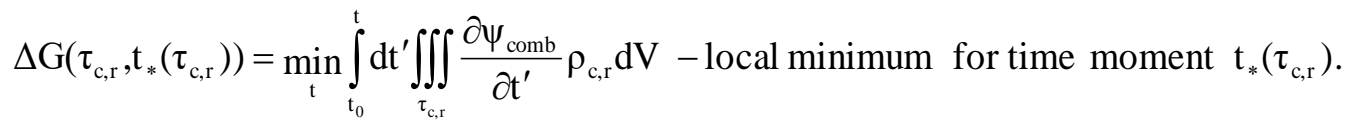

The global prediction thermohydrogravidynamic principles (8) and (9) define the maximal and minimal combined cosmic integral energy gravitational influences ((8) and (9), respectively, for the time moments $\mathrm{t}=\mathrm{t}^{*}\left(\tau_{\mathrm{c}, \mathrm{r}}\right)$ and $\mathrm{t}=\mathrm{t}_{*}\left(\tau_{\mathrm{c}, \mathrm{r}}\right)$ ) on the considered internal rigid core $\tau_{\mathrm{c}, \mathrm{r}}$ (of the Earth) subjected to the combined cosmic integral energy gravitational influence of the planets of the Solar System, the Moon and the Sun (owing to the gravitational interaction of the Sun with the outer large planets).

\section{Findings}

To predict in advance the forthcoming ranges of the next active forthcoming intensifications of the natural (seismotectonic and climatic) processes in California (since 9 August, 2017 and before 3 March, 2018), we use the established [8, 10-12] global prediction thermohydrogravidynamic principle (8) determining the maximal temporal intensification near the time moment $\mathrm{t}=\mathrm{t}^{*}\left(\tau_{\mathrm{c}, \mathrm{r}}\right)$ of the thermohydrogravidynamic processes [10] in the internal rigid core $\tau_{\mathrm{c}, \mathrm{r}}$ and in the boundary region $\tau_{\mathrm{rf}}$ between the internal rigid core $\tau_{\mathrm{c}, \mathrm{r}}$ and the fluid core $\tau_{\mathrm{c}, \mathrm{f}}$ of the Earth. The principle (8) is used to obtain (for the considered real planetary configurations of the Earth and the planets of the Solar System) the numerical time moment $\mathrm{t}^{*}\left(\tau_{\mathrm{c}, \mathrm{r}}, 2017\right)$ corresponding to the maximal (in 2017) combined planetary and solar integral energy gravitational influence (8) on the internal rigid core $\tau_{\mathrm{c}, \mathrm{r}}$ and on the Earth. 
Based on the global prediction thermohydrogravidynamic principle (8) and considering the real planetary configurations of the Earth and the planets of the Solar System for 2017, we obtain (on 10 April, 2017 [15]) the numerical time moment (related with the maximal (in 2017) combined planetary and solar integral energy gravitational influence (8) on the Earth):

$$
\mathrm{t}^{*}\left(\tau_{\mathrm{c}, \mathrm{r}}, 2017\right)=2017.85,
$$

which corresponds approximately to 7 November, 2017.

Based on the global prediction thermohydrogravidynamic principle (8) used for the range (2004 $\div 2016)$, we calculated $[11,12]$ the dates $\mathrm{t}^{*}\left(\tau_{\mathrm{c}, \mathrm{r}},(2004+\mathrm{m})\right) \quad(\mathrm{m}=0,1, \ldots, 12)$ corresponding to the different local maximal and minimal (for the real planetary configurations during the range $(2004 \div 2016)$ ) combined planetary and solar integral energy gravitational influences $((8)$ and (9), respectively) on the Earth. Then we analyze the previous significant (according to the U.S. Geological Survey) and strongest (in each year) earthquakes occurred in California near the calculated dates $\mathrm{t}^{*}\left(\tau_{\mathrm{c}, \mathrm{r}},(2004+\mathrm{m})\right.$ ) corresponding to the maximal (in $2004+\mathrm{m}, \mathrm{m}=0,1, \ldots$, 12) combined planetary and solar integral energy gravitational influence (8) on the Earth for $\mathrm{m}$ $=0,1, \ldots, 12$, correspondingly.

Table 1 presents for $2004(\mathrm{~m}=0)$ the analysis of the previous significant (according to the U.S. Geological Survey) earthquakes occurred in California on dates $t_{e}$ near the calculated date $\mathrm{t}^{*}\left(\tau_{\mathrm{c}, \mathrm{r}}, 2004\right)=2004.6833$ corresponding to the maximal (in 2004) combined planetary and solar integral energy gravitational influence (8) on the internal rigid core $\tau_{\mathrm{c}, \mathrm{r}}$ of the Earth. We see (based on the Table 1) that the first maximal (in 2004) magnitude $M=6.0$ of the first strongest (in 2004) Californian earthquake (occurred on September 28, 2004 in the Central California near the calculated date $\left.\mathrm{t}^{*}\left(\tau_{\mathrm{c}, \mathrm{r}}, 2004\right)=2004.6833\right)$ corresponds to the small difference $\Delta=\left|\mathrm{t}_{\mathrm{e}}-\mathrm{t}^{*}\left(\tau_{\mathrm{c}, \mathrm{r}}, 2004\right)\right|=21.92$ days between the date $\mathrm{t}_{\mathrm{e}}=$ September 28, 2004 $=2004.74332$ of the first strongest (in 2004) Californian earthquake (occurred near the calculated date $\mathrm{t}^{*}\left(\tau_{\mathrm{c}, \mathrm{r}}, 2004\right)=2004$.6833) and the calculated date $\mathrm{t}^{*}\left(\tau_{\mathrm{c}, \mathrm{r}}, 2004\right)=20046833$ We see (based on the Table 1) that the second maximal (in 2004) magnitude $M=5.3$ of the second strongest (in 2004) Californian earthquake (occurred on June 15, 2004 offshore Baja California near the calculated date $\mathrm{t}^{*}\left(\tau_{\mathrm{c}, \mathrm{r}}, 2004\right)=2004$.6833) corresponds to the moderate difference $\Delta=\left|\mathrm{t}_{\mathrm{e}}-\mathrm{t}^{*}\left(\tau_{\mathrm{c}, \mathrm{r}}, 2004\right)\right|=82.38$ days between the date $\mathrm{t}_{\mathrm{e}}=$ June 15,2004 $=2004.45773$ of the second strongest (in 2004) Californian earthquake (occurred near the calculated date $\mathrm{t}^{*}\left(\tau_{\mathrm{c}, \mathrm{r}}, 2004\right)=2004$.6833) and the calculated date $\mathrm{t}^{*}\left(\tau_{\mathrm{c}, \mathrm{r}}, 2004\right)=2004.6833$. 
Table 1: The analysis for $2004(\mathrm{~m}=0)$ of the previous significant (according to the U.S. Geological Survey) earthquakes occurred in California on dates $\mathrm{t}_{\mathrm{e}}$ near the calculated date $\mathrm{t}^{*}\left(\tau_{\mathrm{c}, \mathrm{r}}, 2004\right)=2004.6833$ corresponding to the maximal (in 2004) combined planetary and solar integral energy gravitational influence (8) on the internal rigid core $\tau_{\mathrm{c}, \mathrm{r}}$ of the Earth.

\begin{tabular}{|c|c|c|c|}
\hline $\begin{array}{c}\text { Magnitude M, } \\
\text { Region }\end{array}$ & $\begin{array}{c}\text { Date } \mathrm{t}_{\mathrm{e}} \text { of } \\
\text { earthquake, in } \mathrm{yr}\end{array}$ & $\begin{array}{c}\text { Date } \\
\mathrm{t}^{*}\left(\tau_{\mathrm{c}, \mathrm{r}}, 2004\right)= \\
2004.6833 \text { of the } \\
\text { local maximum }(8) \\
\text { for 2004, in yr }\end{array}$ & $\begin{array}{c}\Delta=\mid \mathrm{t}_{\mathrm{e}}-\mathrm{t}^{*}\left(\tau_{\mathrm{c}, \mathrm{r}}, 2004\right), \\
\text { in days }\end{array}$ \\
\hline $\begin{array}{c}\text { 2004, M=6.0, } \\
\text { Central California }\end{array}$ & $\begin{array}{c}\text { September 28, 2004 } \\
=2004.74332\end{array}$ & $\begin{array}{c}2004.6833 \\
\text { M }\end{array}$ & $\begin{array}{c}21.92 \text { days after the } \\
\text { date } \mathrm{t}^{*}\left(\tau_{\mathrm{c}, \mathrm{r}}, 2004\right)\end{array}$ \\
\hline $\begin{array}{c}\text { Baja California, } \\
\text { Mexico }\end{array}$ & $\begin{array}{c}\text { June 15, 2004 } \\
=2004.45773\end{array}$ & $\begin{array}{c}2004.6833 \\
\text { лок. макс. }\end{array}$ & $\begin{array}{c}82.38 \text { days before the } \\
\text { date } \mathrm{t}^{*}\left(\tau_{\mathrm{c}, \mathrm{r}}, 2004\right)\end{array}$ \\
\hline
\end{tabular}

The obtained small and moderate differences $\Delta=\left|\mathrm{t}_{\mathrm{e}}-\mathrm{t}^{*}\left(\tau_{\mathrm{c}, \mathrm{r}}, 2004\right)\right|=21.92$ days and $\Delta=\left|\mathrm{t}_{\mathrm{e}}-\mathrm{t}^{*}\left(\tau_{\mathrm{c}, \mathrm{r}}, 2004\right)\right|=82.38$ days, respectively, demonstrate the practical applicability of the global prediction thermohydrogravidynamic principle (8) for the reasonable explanation of the strongest seismotectonic activity in California for 2004 near the calculated date $\mathrm{t}^{*}\left(\tau_{\mathrm{c}, \mathrm{r}}, 2004\right)=2004.6833$ corresponding to the maximal (in 2004) combined planetary and solar integral energy gravitational influence (8) on the internal rigid core $\tau_{c, r}$ of the Earth. In addition to Table 1, we present below the results of the analogous analysis for $2009(\mathrm{~m}=5)$, $2013(\mathrm{~m}=9)$ and $2016(\mathrm{~m}=12)$.

Table 2 presents for $2009(\mathrm{~m}=5)$ the analysis of the previous significant (according to the U.S. Geological Survey) earthquakes occurred in California on dates $t_{e}$ near the calculated date $\mathrm{t}^{*}\left(\tau_{\mathrm{c}, \mathrm{r}}, 2009\right)=2009.05$ corresponding to the maximal (in 2009) combined planetary and solar integral energy gravitational influence (8) on the internal rigid core $\tau_{c, r}$ of the Earth. We see (based on the Table 2) that the first maximal (in 2009) magnitude $M=4.8$ of the first strongest (in 2009 for California) earthquake (occurred on March 24, 2009 in the southern California) corresponds to the moderate difference $\Delta=\left|\mathrm{t}_{\mathrm{e}}-\mathrm{t}^{*}\left(\tau_{\mathrm{c}, \mathrm{r}}, 2009\right)\right|=66.61$ days between the date $\mathrm{t}_{\mathrm{e}}$ $=$ March 24, $2009=2009.23237$ of the first strongest (in 2009) Californian earthquake (occurred near the calculated date $\left.\mathrm{t}^{*}\left(\tau_{\mathrm{c}, \mathrm{r}}, 2009\right)=2009.05\right)$ and the calculated date $\mathrm{t}^{*}\left(\tau_{\mathrm{c}, \mathrm{r}}, 2009\right)=2009.05$. 
Table 2: The analysis for $2009(\mathrm{~m}=5)$ of the previous significant (according to the U.S.

Geological Survey) earthquakes occurred in California on dates $\mathrm{t}_{\mathrm{e}}$ near the calculated date $\mathrm{t}^{*}\left(\tau_{\mathrm{c}, \mathrm{r}}, 2009\right)=2009.05$ corresponding to the maximal (in 2009) combined planetary and solar integral energy gravitational influence (8) on the internal rigid core $\tau_{c, r}$ of the Earth.

\begin{tabular}{|c|c|c|c|}
\hline $\begin{array}{l}\text { Magnitude } M \text {, } \\
\text { Region }\end{array}$ & $\begin{array}{c}\text { Date } \mathrm{t}_{\mathrm{e}} \text { of } \\
\text { earthquake, in } \mathrm{yr}\end{array}$ & $\begin{array}{c}\text { Date } \\
\mathrm{t}^{*}\left(\tau_{\mathrm{c}, \mathrm{r}}, 2009\right)= \\
2009.05 \text { of the local } \\
\text { maximum }(8) \text { for } \\
2009, \text { in } \mathrm{yr}\end{array}$ & $\begin{array}{c}\Delta=\left|\mathrm{t}_{\mathrm{e}}-\mathrm{t}^{*}\left(\tau_{\mathrm{c}, \mathrm{r}}, 2009\right)\right| \\
\text { in days }\end{array}$ \\
\hline $\begin{array}{c}\mathrm{M}=4.3, \text { Northern } \\
\text { California }\end{array}$ & $\begin{array}{l}\text { March 30, } 2009 \\
=2009.2488\end{array}$ & 2009.05 & $\begin{array}{l}72.61 \text { days after the } \\
\text { date } \mathrm{t}^{*}\left(\tau_{\mathrm{c}, \mathrm{r}}, 2009\right)\end{array}$ \\
\hline $\begin{array}{l}\qquad \mathrm{M}=\mathbf{4 . 8} \\
\text { Southern California }\end{array}$ & $\begin{array}{l}\text { March 24, } 2009 \\
=2009.23237\end{array}$ & 2009.05 & $\begin{array}{l}66.61 \text { days after the } \\
\text { date } \mathrm{t}^{*}\left(\tau_{\mathrm{c}, \mathrm{r}}, 2009\right)\end{array}$ \\
\hline $\begin{array}{c}\mathrm{M}=3.5, \text { San } \\
\text { Francisco Bay Area, } \\
\text { California }\end{array}$ & $\begin{array}{l}\text { March 8, } 2009 \\
=2009.18856\end{array}$ & 2009.05 & $\begin{array}{l}50.60 \text { days after the } \\
\text { date } \mathrm{t}^{*}\left(\tau_{\mathrm{c}, \mathrm{r}}, 2009\right)\end{array}$ \\
\hline $\begin{array}{c}\mathrm{M}=\mathbf{4 . 5}, \text { Greater Los } \\
\text { Angeles Area, } \\
\text { California }\end{array}$ & $\begin{array}{l}\text { January 9, } 2009 \\
=2009.02464\end{array}$ & 2009.05 & $\begin{array}{l}9.25 \text { days before of the } \\
\text { date } t^{*}\left(\tau_{c, r}, 2009\right)\end{array}$ \\
\hline
\end{tabular}

We see (based on the Table 2) that the second maximal (in 2009) magnitude $M=4.5$ of the second strongest (in 2009 for California) earthquake (occurred on January 9, 2009 in the Greater Los Angeles Area) corresponds to the small difference $\Delta=\left|\mathrm{t}_{\mathrm{e}}-\mathrm{t}^{*}\left(\tau_{\mathrm{c}, \mathrm{r}}, 2009\right)\right|=9.25$ days between the date $\mathrm{t}_{\mathrm{e}}=$ January 9, $2009=2009.02464$ of the second strongest (in 2009) Californian earthquake (occurred near the calculated date $\left.\mathrm{t}^{*}\left(\tau_{\mathrm{c}, \mathrm{r}}, 2009\right)=2009.05\right)$ and the calculated date $\left.\mathrm{t}^{*}\left(\tau_{\mathrm{c}, \mathrm{r}}, 2009\right)=2009.05\right)$. The obtained moderate and small differences $\Delta=\left|\mathrm{t}_{\mathrm{e}}-\mathrm{t}^{*}\left(\tau_{\mathrm{c}, \mathrm{r}}, 2009\right)\right|=66.61$ days and $\Delta=\left|\mathrm{t}_{\mathrm{e}}-\mathrm{t}^{*}\left(\tau_{\mathrm{c}, \mathrm{r}}, 2009\right)\right|=9.25$ days, respectively, demonstrate the practical applicability of the global prediction thermohydrogravidynamic principle (8) for the reasonable explanation of the strongest seismotectonic activity in California for 2009 near the calculated date $\mathrm{t}^{*}\left(\tau_{\mathrm{c}, \mathrm{r}}, 2009\right)=2009.05$ corresponding to the maximal (in 2009) combined planetary and solar integral energy gravitational influence (8) on the internal rigid core $\tau_{\mathrm{c}, \mathrm{r}}$ of the Earth. 
Table 3: The analysis for $2013(\mathrm{~m}=9)$ of the previous significant (according to the U.S. Geological Survey) earthquakes occurred in California on dates $t_{\mathrm{e}}$ near the calculated date $\mathrm{t}^{*}\left(\tau_{\mathrm{c}, \mathrm{r}}, 2013\right)=2013.4666$ corresponding to the maximal (in 2013) combined planetary and solar integral energy gravitational influence (8) on the internal rigid core $\tau_{\mathrm{c}, \mathrm{r}}$ of the Earth.

\begin{tabular}{|c|c|c|c|}
\hline $\begin{array}{l}\text { Magnitude M, } \\
\text { Region }\end{array}$ & $\begin{array}{c}\text { Date } t_{\mathrm{e}} \text { of earthquake, } \\
\text { in } \mathrm{yr}\end{array}$ & $\begin{array}{c}\text { Date } \\
\mathrm{t}^{*}\left(\tau_{\mathrm{c}, \mathrm{r}}, 2013\right)= \\
2013.4666 \text { of the } \\
\text { local maximum }(8) \\
\text { for } 2013, \text { in } \mathrm{yr}\end{array}$ & $\begin{array}{c}\Delta=\left|\mathrm{t}_{\mathrm{e}}-\mathrm{t}^{*}\left(\tau_{\mathrm{c}, \mathrm{r}}, 2013\right)\right| \\
\text { in days }\end{array}$ \\
\hline $\begin{array}{l}\mathrm{M}=3.8,2 \mathrm{~km} \mathrm{SW} \text { of } \\
\mathrm{La} \text { Verne, California }\end{array}$ & $\begin{array}{l}\text { September } 19,2013 \\
=2013.71868\end{array}$ & 2013.4666 & $\begin{array}{l}92.07 \text { days after of the } \\
\text { date } \mathrm{t}^{*}\left(\tau_{\mathrm{c}, \mathrm{r}}, 2013\right)\end{array}$ \\
\hline $\begin{array}{c}\mathrm{M}=4.5,18 \mathrm{~km} \\
\text { WNW of Bayview, } \\
\text { California }\end{array}$ & $\begin{array}{l}\text { August 3, } 2013 \\
=2013.59154\end{array}$ & 2013.4666 & $\begin{array}{l}45.63 \text { days after of the } \\
\text { date } \mathrm{t}^{*}\left(\tau_{\mathrm{c}, \mathrm{r}}, 2013\right)\end{array}$ \\
\hline $\begin{array}{l}\mathrm{M}=\mathbf{4 . 8}, 5 \mathrm{~km} \mathrm{~W} \text { of } \\
\text { Isla Vista, California }\end{array}$ & $\begin{array}{l}\text { May 29, } 2013 \\
=2013.41273\end{array}$ & 2013.4666 & $\begin{array}{l}19.67 \text { days before of } \\
\text { the date } t^{*}\left(\tau_{c, r}, 2013\right)\end{array}$ \\
\hline $\begin{array}{c}\mathrm{M}=\mathbf{5 . 7}, 10 \mathrm{~km} \\
\text { WNW of Greenville, } \\
\text { California }\end{array}$ & $\begin{array}{l}\text { May 24, } 2013 \\
=2013.39904\end{array}$ & 2013.4666 & $\begin{array}{l}24.67 \text { days before of } \\
\text { the date } t^{*}\left(\tau_{c, r}, 2013\right)\end{array}$ \\
\hline $\begin{array}{c}\mathrm{M}=4.7,20 \mathrm{~km} \text { ESE } \\
\text { of Anza, California }\end{array}$ & $\begin{array}{c}\text { March 11, } 2013 \\
=2013.19678\end{array}$ & 2013.4666 & $\begin{array}{l}98.55 \text { days before of } \\
\text { the date } t^{*}\left(\tau_{c, r}, 2013\right)\end{array}$ \\
\hline
\end{tabular}

Table 3 presents for $2013(\mathrm{~m}=9)$ the analysis of the previous significant (according to the U.S. Geological Survey) earthquakes occurred in California on dates $t_{e}$ near the calculated date $\mathrm{t}^{*}\left(\tau_{\mathrm{c}, \mathrm{r}}, 2013\right)=2013.4666$ corresponding to the maximal (in 2013) combined planetary and solar integral energy gravitational influence (8) on the internal rigid core $\tau_{\mathrm{c}, \mathrm{r}}$ of the Earth. We see (based on the Table 3) that the first maximal (in 2013) magnitude $\mathrm{M}=5.7$ of the first strongest (in 2013 for California) earthquake (occurred on May 24, 2013 near $10 \mathrm{~km} \mathrm{WNW} \mathrm{of}$ Greenville, California) corresponds to the small difference $\Delta=\left|\mathrm{t}_{\mathrm{e}}-\mathrm{t}^{*}\left(\tau_{\mathrm{c}, \mathrm{r}}, 2013\right)\right|=24.67$ days between the date $t_{e}=$ May 24, $2013=2013.39904$ of the first strongest (in 2013) Californian earthquake (occurred near the calculated date $\left.t^{*}\left(\tau_{c, r}, 2013\right)=2013.4666\right)$ and the calculated date $\mathrm{t}^{*}\left(\tau_{\mathrm{c}, \mathrm{r}}, 2013\right)=2013.461 \mathrm{We}$ see (based on the Table 3 ) that the second maximal (in 2013) magnitude $M=4.8$ of the second strongest (in 2013 for California) earthquake (occurred on May 29, 2013 near $5 \mathrm{~km} \mathrm{~W}$ of Isla Vista, California) corresponds to the small difference $\Delta=\left|\mathrm{t}_{\mathrm{e}}-\mathrm{t}^{*}\left(\tau_{\mathrm{c}, \mathrm{r}}, 2013\right)\right|=19.67$ days between the date $\mathrm{t}_{\mathrm{e}}=$ May $29,2013=2013.41273$ of the second strongest (in 2013) Californian earthquake (occurred near the calculated date $\left.\mathrm{t}^{*}\left(\tau_{\mathrm{c}, \mathrm{r}}, 2013\right)=2013.4666\right)$ and the calculated date $\mathrm{t}^{*}\left(\tau_{\mathrm{c}, \mathrm{r}}, 2013\right)=2013.4666$. The obtained small differences $\Delta=\left|\mathrm{t}_{\mathrm{e}}-\mathrm{t}^{*}\left(\tau_{\mathrm{c}, \mathrm{r}}, 2013\right)\right|=24.67$ days and $\Delta=\left|\mathrm{t}_{\mathrm{e}}-\mathrm{t}^{*}\left(\tau_{\mathrm{c}, \mathrm{r}}, 2013\right)\right|=19.67$ days 
demonstrate the practical applicability of the global prediction thermohydrogravidynamic principle (8) for the reasonable explanation of the strongest seismotectonic activity in California for 2013 near the calculated date $\mathrm{t}^{*}\left(\tau_{c, \mathrm{r}}, 2013\right)=2013.4666$ corresponding to the maximal (in 2013) combined planetary and solar integral energy gravitational influence (8) on the internal rigid core $\tau_{\mathrm{c}, \mathrm{r}}$ of the Earth.

Table 4 presents for $2016(\mathrm{~m}=12)$ the analysis of the previous significant (according to the U.S. Geological Survey) earthquakes occurred in California on dates $t_{e}$ near the calculated date $\mathrm{t}^{*}\left(\tau_{\mathrm{c}, \mathrm{r}}, 2016\right)=2016.7666$ corresponding to the maximal (in 2016) combined planetary and solar integral energy gravitational influence (8) on the internal rigid core $\tau_{c, r}$ of the Earth. We see (based on the Table 4) that the first maximal (in 2016) magnitude $M=6.6$ of the first strongest (in 2016 for California) earthquake (occurred on December 8, 2016 near $164 \mathrm{~km} \mathrm{~W}$ of Ferndale, California) corresponds to the moderate difference $\Delta=\left|\mathrm{t}_{\mathrm{e}}-\mathrm{t}^{*}\left(\tau_{\mathrm{c}, \mathrm{r}}, 2016\right)\right|=62.8$ days between the date $t_{e}=$ December $8,2016=2016.93856$ of the first strongest (in 2016) Californian earthquake (occurred near the calculated date $\left.t^{*}\left(\tau_{c, r}, 2016\right)=2016.7666\right)$ and the calculated date $\mathrm{t}^{*}\left(\tau_{c, \mathrm{r}}, 2016\right)=2016.7666$.

Table 4: The analysis for $2016(\mathrm{~m}=12)$ of the previous significant (according to the U.S. Geological Survey) earthquakes occurred in California on dates $t_{e}$ near the calculated date $\mathrm{t}^{*}\left(\tau_{\mathrm{c}, \mathrm{r}}, 2016\right)=2016.7666$ corresponding to the maximal (in 2016) combined planetary and solar integral energy gravitational influence (8) on the internal rigid core $\tau_{c, \mathrm{r}}$ of the Earth.

\begin{tabular}{|c|c|c|c|}
\hline $\begin{array}{l}\text { Magnitude } \mathrm{M}, \\
\text { Region }\end{array}$ & $\begin{array}{c}\text { Date } t_{e} \text { of } \\
\text { earthquake, in } y r\end{array}$ & $\begin{array}{c}\text { Date } \\
t^{*}\left(\tau_{c, r}, 2016\right)= \\
2016.7666 \text { of the } \\
\text { local maximum (8) } \\
\text { for } 2016, \text { in yr }\end{array}$ & $\begin{array}{c}\Delta=\left|\mathrm{t}_{\mathrm{e}}-\mathrm{t}^{*}\left(\tau_{\mathrm{c}, \mathrm{r}}, 2016\right)\right| \\
\text { in days }\end{array}$ \\
\hline $\begin{array}{c}\mathrm{M}=4.0,9 \mathrm{~km} \mathrm{~W} \text { of } \\
\text { Templeton, } \\
\text { California }\end{array}$ & $\begin{array}{l}\text { December } 14,2016 \\
\quad=2016.95499\end{array}$ & 2016.7666 & $\begin{array}{l}68.8 \text { days after the date } \\
\mathrm{t}^{*}\left(\tau_{\mathrm{c}, \mathrm{r}}, 2016\right)\end{array}$ \\
\hline $\begin{array}{c}\mathrm{M}=\mathbf{6 . 6}, 164 \mathrm{~km} \mathrm{~W} \\
\text { of Ferndale, } \\
\text { California }\end{array}$ & $\begin{array}{l}\text { December } 8,2016 \\
=2016.93856\end{array}$ & 2016.7666 & $\begin{array}{l}62.8 \text { days after the date } \\
\mathrm{t}^{*}\left(\tau_{\mathrm{c}, \mathrm{r}}, 2016\right)\end{array}$ \\
\hline $\begin{array}{c}\mathrm{M}=3.7,5 \mathrm{~km} \mathrm{~S} \text { of } \\
\text { Loma Linda, } \mathrm{CA}\end{array}$ & $\begin{array}{l}\text { October } 8,2016 \\
=2016.7719\end{array}$ & 2016.7666 & $\begin{array}{l}1.9 \text { days after the date } \\
\mathrm{t}^{*}\left(\tau_{\mathrm{c}, \mathrm{r}}, 2016\right)\end{array}$ \\
\hline $\begin{aligned} \mathrm{M}= & 3.5,3 \mathrm{~km} \mathrm{SE} \text { of } \\
& \text { Piedmont, } \\
& \text { California }\end{aligned}$ & $\begin{array}{l}\text { September 13, } 2016 \\
=2016.70225\end{array}$ & 2016.7666 & $\begin{array}{l}23.5 \text { days before the } \\
\text { date } \mathrm{t}^{*}\left(\tau_{\mathrm{c}, \mathrm{r}}, 2016\right)\end{array}$ \\
\hline $\begin{array}{c}\mathrm{M}=\mathbf{5 . 6}, 100 \mathrm{~km} \mathrm{~W} \\
\text { of Ferndale, } \\
\text { California }\end{array}$ & $\begin{array}{l}\text { September 3, } 2016 \\
\quad=2016.67488\end{array}$ & 2016.7666 & $\begin{array}{l}33.5 \text { days before the } \\
\text { date } \mathrm{t}^{*}\left(\tau_{\mathrm{c}, \mathrm{r}}, 2016\right)\end{array}$ \\
\hline
\end{tabular}


DOI: 10.5281/zenodo.1040246

\begin{tabular}{|c|c|c|c|}
\hline $\begin{array}{c}\mathrm{M}=5.1,20 \mathrm{~km} \mathrm{NNE} \\
\text { of Upper Lake, } \\
\text { California }\end{array}$ & $\begin{array}{l}\text { August } 10,2016 \\
=2016.61071\end{array}$ & 2016.7666 & $\begin{array}{l}56.93 \text { days before the } \\
\text { date } \mathrm{t}^{*}\left(\tau_{\mathrm{c}, \mathrm{r}}, 2016\right)\end{array}$ \\
\hline $\begin{array}{c}\mathrm{M}=4.5,30 \mathrm{~km} \mathrm{ESE} \\
\text { of Janesville, } \\
\text { California }\end{array}$ & $\begin{array}{l}\text { August } 4,2016 \\
=2016.59428\end{array}$ & 2016.7666 & $\begin{array}{l}62.93 \text { days before the } \\
\text { date } \mathrm{t}^{*}\left(\tau_{\mathrm{c}, \mathrm{r}}, 2016\right)\end{array}$ \\
\hline $\begin{array}{c}\mathrm{M}=4.7,19 \mathrm{~km} \text { SE of } \\
\text { Bayside, } \\
\text { California }\end{array}$ & $\begin{array}{l}\text { July } 21,2016 \\
=2016.55749\end{array}$ & 2016.7666 & $\begin{array}{l}\text { 76.37 days before the } \\
\text { date } \mathrm{t}^{*}\left(\tau_{\mathrm{c}, \mathrm{r}}, 2016\right)\end{array}$ \\
\hline $\begin{array}{c}\mathrm{M}=4.2,13 \mathrm{~km} \mathrm{SSE} \\
\text { of Ridgemark, } \\
\text { California }\end{array}$ & $\begin{array}{l}\text { July } 19,2016 \\
=2016.55201\end{array}$ & 2016.7666 & $\begin{array}{l}\text { 78.37 days before the } \\
\text { date } \mathrm{t}^{*}\left(\tau_{\mathrm{c}, \mathrm{r}}, 2016\right)\end{array}$ \\
\hline
\end{tabular}

We see (based on the Table 4) that the second maximal (in 2016) magnitude $M=5.6$ of the second strongest (in 2016 for California) earthquake (occurred on September 3, 2016 near 100 $\mathrm{km} \mathrm{W}$ of Ferndale, California) corresponds to the moderate difference $\Delta=\left|\mathrm{t}_{\mathrm{e}}-\mathrm{t}^{*}\left(\tau_{\mathrm{c}, \mathrm{r}}, 2013\right)\right|=$ 33.5 days between the date $t_{e}=$ September 3, $2016=2016.67488$ of the second strongest (in 2016) Californian earthquake (occurred near the calculated date $t^{*}\left(\tau_{c, r}, 2016\right)=2016.7666$ ) and the calculated date $\mathrm{t}^{*}\left(\tau_{\mathrm{c}, \mathrm{r}}, 2016\right)=2016.7666$. The obtained moderate differences $\Delta=\left|\mathrm{t}_{\mathrm{e}}-\mathrm{t}^{*}\left(\tau_{\mathrm{c}, \mathrm{r}}, 2016\right)\right|=62.8$ days and $\Delta=\left|\mathrm{t}_{\mathrm{e}}-\mathrm{t}^{*}\left(\tau_{\mathrm{c}, \mathrm{r}}, 2013\right)\right|=33.5$ days demonstrate the practical applicability of the global prediction thermohydrogravidynamic principle (8) for the reasonable explanation of the strongest seismotectonic activity in California for 2016 near the calculated date $\mathrm{t}^{*}\left(\tau_{\mathrm{c}, \mathrm{r}}, 2016\right)=2016.7666$ corresponding to the maximal (in 2016) combined planetary and solar integral energy gravitational influence (8) on the internal rigid core $\tau_{c, r}$ of the Earth.

Considering the range $(2004 \div 2016)$ and analyzing the previous significant and strongest (in each year) earthquakes (occurred in California near the calculated dates $\mathrm{t}^{*}\left(\tau_{\mathrm{c}, \mathrm{r}},(2004+\mathrm{m})\right.$ ) corresponding to the maximal (in $2004+\mathrm{m}, \mathrm{m}=0,1, \ldots, 12$ ) combined planetary and solar integral energy gravitational influences (8) on the internal rigid core $\tau_{\mathrm{c}, \mathrm{r}}$ of the Earth for $\mathrm{m}=0$, $1, \ldots, 12$, correspondingly), we calculated (on 9 August, 2017) the following probabilities

$\operatorname{Pr}\left\{\mathrm{t}_{\mathrm{e}, \max , 2017} \in(26\right.$ October $\div 7$ November, 2017) $\}=0.0769$,

$\operatorname{Pr}\left\{\mathrm{t}_{\mathrm{e}, \max , 2017} \in(23\right.$ October $\div 7$ November, 2017) $\}=0.1538$,

$\operatorname{Pr}\left\{\mathrm{t}_{\mathrm{e}, \max , 2017} \in(15\right.$ October $\div 7$ November, 2017) $\}=0.2307$,

$\operatorname{Pr}\left\{\mathrm{t}_{\mathrm{e}, \max , 2017} \in(13\right.$ October $\div 7$ November, 2017) $\}=0.3076$,

$\operatorname{Pr}\left\{\mathrm{t}_{\mathrm{e}, \max , 2017} \in(7\right.$ October $\div 7$ November, 2017) $\}=0.3846$,

$\operatorname{Pr}\left\{\mathrm{t}_{\mathrm{e}, \max , 2017} \in(25\right.$ September $\div 7$ November, 2017) $\}=0.4615$,

$\operatorname{Pr}\left\{\mathrm{t}_{\mathrm{e}, \max , 2017} \in(17\right.$ September $\div 7$ November, 2017) $\}=0.5384$,

$\operatorname{Pr}\left\{\mathrm{t}_{\mathrm{e}, \max , 2017} \in(9\right.$ August $\div 7$ November, 2017) $\}=0.6153$, 


$$
\begin{aligned}
& \operatorname{Pr}\left\{\mathrm{t}_{\mathrm{e}, \max , 2017} \in(9 \text { August } \div 29 \text { November, 2017) }\}=0.6923\right. \text {, } \\
& \operatorname{Pr}\left\{\mathrm{t}_{\mathrm{e}, \max , 2017} \in(9 \text { August } \div 8 \text { December, 2017) }\}=0.7692\right. \text {, } \\
& \operatorname{Pr}\left\{\mathrm{t}_{\mathrm{e}, \max , 2017} \in(9 \text { August, } 2017 \div 9 \text { January, 2018) }\}=0.8461\right. \text {, } \\
& \operatorname{Pr}\left\{\mathrm{t}_{\mathrm{e}, \max , 2017-2018} \in \text { (9 August, 2017 } \div \text { 13 January, 2018) }\right\}=0.923 \text {, } \\
& \operatorname{Pr}\left\{\mathrm{t}_{\mathrm{e}, \max , 2017} \in(9 \text { August, } 2017 \div 3 \text { March, 2018) }\}=0.99\right.
\end{aligned}
$$

of the forthcoming strongest (in California) earthquakes (and related [4, 7-12, 14] strongest (in 2017 and 2018) climatic processes since 9 August, 2017 and before 3 March, 2018) near the numerical time moment $\mathrm{t}^{*}\left(\tau_{\mathrm{c}, \mathrm{r}}, 2017\right)=2017.85$ corresponding approximately to 7 November, 2017) during the calculated (on 9 August, 2017) following ranges:

$$
\begin{aligned}
& \text { (26October } \div 7 \text { November, 2017), } \\
& \text { (23October } \div 7 \text { November, 2017), } \\
& \text { (15October } \div 7 \text { November, 2017), } \\
& \text { (13October } \div 7 \text { November, 2017), } \\
& \text { (7 October } \div 7 \text { November, 2017), } \\
& \text { (25September } \div 7 \text { November, 2017), } \\
& \text { (17September } \div 7 \text { November, 2017), } \\
& \text { (9 August } \div 7 \text { November, 2017), } \\
& \text { (9 August } \div 29 \text { November, 2017), } \\
& \text { (9 August } \div 8 \text { December,2017), } \\
& \text { (9 August,2017 } \div 9 \text { January, 2018), } \\
& \text { (9 August, 2017 } \div 13 \text { January, 2018), } \\
& \text { (9 August, 2017 } \div 3 \text { March, 2018). }
\end{aligned}
$$

It means that the dates $t_{e, \text { max,2017 }}$ and $t_{e, \max , 2017-2018}$ of the forthcoming strongest earthquakes (and related $[4,7-12,14]$ strongest climatic processes in California determined by the maximal (in 2017) combined planetary and solar integral energy gravitational influence (8) on the internal rigid core $\tau_{c, r}$ of the Earth near the numerical time moment $\mathrm{t}^{*}\left(\tau_{\mathrm{c}, \mathrm{r}}, 2017\right)=2017.85$ corresponding approximately to 7 November, 2017) will occur during the ranges (24), (25), (26), (27), (28), (29), (30), (31), (32), (33), (34), (35) and (36) characterized by the probabilities (11), (12), (13), (14), (15), (15), (16), (17), (18), (19), (20), (21), (22) and (23), correspondingly. These ranges (24) - (36) and the corresponding probabilities (11) - (23) were founded (on 9 August, 2017) exceptionally (by eliminating the analysis of the strongest climatic activity in California during the range $(2004 \div 2016)$ ) based on the combined analysis of the dates of the previous strongest (according to the U.S. Geological Survey) earthquakes occurred in California during the range $(2004 \div 2016)$ near the calculated dates $\mathrm{t}^{*}\left(\tau_{\mathrm{c}, \mathrm{r}},(2004+\mathrm{m})\right) \quad(\mathrm{m}=0,1, \ldots, 12)$ corresponding to the different local maxima (8) of the combined planetary and solar integral energy gravitational influences (related with the real planetary configurations during the range $(2004 \div 2017)$ ) on the internal rigid core $\tau_{c, r}$ of the Earth and on the Earth as a whole. 


\section{Discussions}

We have presented in Section 3 (Findings) the results (for $2004(\mathrm{~m}=0), 2009(\mathrm{~m}=5), 2013(\mathrm{~m}=$ 9) and $2016(\mathrm{~m}=12)$ ) of the analysis of the previous significant (according to the U.S. Geological Survey) earthquakes (occurred in California near the calculated dates $\mathrm{t}^{*}\left(\tau_{\mathrm{c}, \mathrm{r}},(2004+\mathrm{m})\right)(\mathrm{m}=0,5,9,12)$ corresponding to the different local maxima (8) of the combined planetary and solar integral energy gravitational influences (on the internal rigid core $\tau_{\mathrm{c}, \mathrm{r}}$ of the Earth) related with the real planetary configurations during the range $(2004 \div 2017)$ ) concerning the closeness of the calculated dates $\mathrm{t}^{*}\left(\tau_{\mathrm{c}, \mathrm{r}},(2004+\mathrm{m})\right)(\mathrm{m}=0,5,9,12)$ to the real dates of the occurred significant (according to the U.S. Geological Survey) earthquakes in California.

We have shown (based on the Table 1) that the obtained small and moderate (respectively) differences $\Delta=\left|\mathrm{t}_{\mathrm{e}}-\mathrm{t}^{*}\left(\tau_{\mathrm{c}, \mathrm{r}}, 2004\right)\right|=21.92$ days (between the date $\mathrm{t}_{\mathrm{e}}=$ September 28, 2004 $=2004.74332$ of the first strongest (in 2004) Californian 6-magnitude earthquake (occurred near the calculated date $\left.\mathrm{t}^{*}\left(\tau_{\mathrm{c}, \mathrm{r}}, 2004\right)=2004.6833\right)$ and the calculated date $\left.\mathrm{t}^{*}\left(\tau_{\mathrm{c}, \mathrm{r}}, 2004\right)=2004.6833\right)$ and $\Delta=\left|\mathrm{t}_{\mathrm{e}}-\mathrm{t}^{*}\left(\tau_{\mathrm{c}, \mathrm{r}}, 2004\right)\right|=82.38$ days (between the date $\mathrm{t}_{\mathrm{e}}=$ June 15, $2004=2004.45773$ of the second strongest (in 2004) Californian 5.3-magnitude earthquake (occurred near the calculated date $\mathrm{t}^{*}\left(\tau_{\mathrm{c}, \mathrm{r}}, 2004\right)=2004.6833$ ) and the calculated date $\left.\mathrm{t}^{*}\left(\tau_{\mathrm{c}, \mathrm{r}}, 2004\right)=2004.6833\right)$ demonstrate the practical applicability of the global prediction thermohydrogravidynamic principle (8) for the reasonable explanation of the strongest seismotectonic activity in California for 2004 near the calculated date $\mathrm{t}^{*}\left(\tau_{\mathrm{c}, \mathrm{r}}, 2004\right)=2004.6833$ corresponding to the maximal (in 2004) combined planetary and solar integral energy gravitational influence (8) on the internal rigid core $\tau_{c, r}$ of the Earth.

We have shown (based on the Table 2) that the obtained moderate and small (respectively) differences $\Delta=\left|\mathrm{t}_{\mathrm{e}}-\mathrm{t}^{*}\left(\tau_{\mathrm{c}, \mathrm{r}}, 2009\right)\right|=66.61$ days (between the date $\mathrm{t}_{\mathrm{e}}=$ March 24, 2009 $=2009.23237$ of the first strongest (in 2009) Californian 4.8-magnitude earthquake (occurred near the calculated date $\left.\mathrm{t}^{*}\left(\tau_{\mathrm{c}, \mathrm{r}}, 2009\right)=2009.05\right)$ and the calculated date $\left.\mathrm{t}^{*}\left(\tau_{\mathrm{c}, \mathrm{r}}, 2009\right)=2009.05\right)$ and $\Delta=\left|\mathrm{t}_{\mathrm{e}}-\mathrm{t}^{*}\left(\tau_{\mathrm{c}, \mathrm{r}}, 2009\right)\right|=9.25$ days (between the date $\mathrm{t}_{\mathrm{e}}=$ January $9,2009=2009.02464$ of the second strongest (in 2009) Californian 4.5-magnitude earthquake (occurred near the calculated date $\left.\mathrm{t}^{*}\left(\tau_{\mathrm{c}, \mathrm{r}}, 2009\right)=2009.05\right)$ and the calculated date $\left.\mathrm{t}^{*}\left(\tau_{\mathrm{c}, \mathrm{r}}, 2009\right)=2009.05\right)$ demonstrate the practical applicability of the global prediction thermohydrogravidynamic principle (8) for the reasonable explanation of the strongest seismotectonic activity in California for 2009 near the calculated date $t^{*}\left(\tau_{c, r}, 2009\right)=2009.05$ corresponding to the maximal (in 2009) combined planetary and solar integral energy gravitational influence (8) on the internal rigid core $\tau_{\mathrm{c}, \mathrm{r}}$ of the Earth. 
We have shown (based on the Table 3) that the obtained small differences $\Delta=\left|\mathrm{t}_{\mathrm{e}}-\mathrm{t}^{*}\left(\tau_{\mathrm{c}, \mathrm{r}}, 2013\right)\right|=24.67$ days (between the date $\mathrm{t}_{\mathrm{e}}=$ May $24,2013=2013.39904 \mathrm{of}$ the first strongest (in 2013) Californian 5.7-magnitude earthquake (occurred near the calculated date $\left.t^{*}\left(\tau_{c, r}, 2013\right)=2013.4666\right)$ and the calculated date $\left.t^{*}\left(\tau_{c, r}, 2013\right)=2013.4666\right)$ and $\Delta=\left|\mathrm{t}_{\mathrm{e}}-\mathrm{t}^{*}\left(\tau_{\mathrm{c}, \mathrm{r}}, 2013\right)\right|=19.67$ days (between the date $\mathrm{t}_{\mathrm{e}}=$ May $29,2013=2013.41273$ of the second strongest (in 2013) Californian 4.8-magnitude earthquake (occurred near the calculated date $\left.\mathrm{t}^{*}\left(\tau_{\mathrm{c}, \mathrm{r}}, 2013\right)=2013.4666\right)$ and the calculated date $\left.\mathrm{t}^{*}\left(\tau_{\mathrm{c}, \mathrm{r}}, 2013\right)=2013.4666\right)$ demonstrate the practical applicability of the global prediction thermohydrogravidynamic principle (8) for the reasonable explanation of the strongest seismotectonic activity in California for 2013 near the calculated date $\mathrm{t}^{*}\left(\tau_{\mathrm{c}, \mathrm{r}}, 2013\right)=2013.4666$ corresponding to the maximal (in 2013) combined planetary and solar integral energy gravitational influence (8) on the internal rigid core $\tau_{\mathrm{c}, \mathrm{r}}$ of the Earth.

We have shown (based on the Table 4) that the obtained moderate differences $\Delta=\left|\mathrm{t}_{\mathrm{e}}-\mathrm{t}^{*}\left(\tau_{\mathrm{c}, \mathrm{r}}, 2016\right)\right|=62.8$ days (between the date $\mathrm{t}_{\mathrm{e}}=$ December $8,2016=2016.93856$ of the first strongest (in 2016) Californian 6.6-magnitude earthquake (occurred near the calculated date $\left.\mathrm{t}^{*}\left(\tau_{\mathrm{c}, \mathrm{r}}, 2016\right)=2016.7666\right)$ and the calculated date $\left.\mathrm{t}^{*}\left(\tau_{\mathrm{c}, \mathrm{r}}, 201\right) 6=2016.\right)$ and $\Delta=\left|\mathrm{t}_{\mathrm{e}}-\mathrm{t}^{*}\left(\tau_{\mathrm{c}, \mathrm{r}}, 2013\right)\right|=33.5$ days (between the date $\mathrm{t}_{\mathrm{e}}=$ September $3,2016=2016.67488$ of the second strongest (in 2016) Californian 5.6-magnitude earthquake (occurred near the calculated date $\left.\mathrm{t}^{*}\left(\tau_{\mathrm{c}, \mathrm{r}}, 2016\right)=2016.7666\right)$ and the calculated date $\left.\mathrm{t}^{*}\left(\tau_{\mathrm{c}, \mathrm{r}}, 2016\right)=2016.7666\right)$ demonstrate the practical applicability of the global prediction thermohydrogravidynamic principle (8) for the reasonable explanation of the strongest seismotectonic activity in California for 2016 near the calculated date $\mathrm{t}^{*}\left(\tau_{\mathrm{c}, \mathrm{r}}, 2016\right)=2016.7666$ corresponding to the maximal (in 2016) combined planetary and solar integral energy gravitational influence (8) on the internal rigid core $\tau_{\mathrm{c}, \mathrm{r}}$ of the Earth.

We have presented in Section 3 (Findings) the prediction (made on 9 August, 2017 based on the global prediction thermohydrogravidynamic principle (8) of the cosmic seismology [8, 10-12]) concerning the strongest intensifications of the (closely related $[4,7-12,14]$ ) seismotectonic and climatic processes in California (since 9 August, 2017 and before 3 March, 2018) determined by the maximal (in 2017 for the time moment $\mathrm{t}^{*}\left(\tau_{\mathrm{c}, \mathrm{r}}, 2017\right)=2017.85$, which corresponds approximately to 7 November, 2017) combined planetary and solar integral energy gravitational influences on the internal rigid core $\tau_{\mathrm{c}, \mathrm{r}}$ of the Earth. Considering the range $(2004 \div 2016)$ and analyzing the previous significant (according to the U.S. Geological Survey) and strongest (in each year) earthquakes (occurred in California near the calculated dates $t^{*}\left(\tau_{c, r},(2004+\mathrm{m})\right)(\mathrm{m}$ $=0,1, \ldots, 12)$ corresponding to the different local maxima (8) of the combined planetary and solar integral energy gravitational influences related with the real planetary configurations during the range (2004 $\div 2017)$ ), we have founded the ranges (24), (25), (26), (27), (28), (29), (30), (31), (32), (33), (34), (35) and (36) of the dates $t_{e, \max , 2017}$ and $t_{\mathrm{e}, \max , 2017-2018}$ of the forthcoming strongest 
Californian earthquakes (and related [4, 7-12, 14] strongest climatic processes in California determined by the maximal combined planetary and solar integral energy gravitational influence (8) on the internal rigid core $\tau_{c, r}$ of the Earth in 2017 near the numerical time moment $\mathrm{t}^{*}\left(\tau_{\mathrm{c}, \mathrm{r}}, 2017\right)=2017.85$ corresponding approximately to 7 November, 2017) characterized by the probabilities (11), (12), (13), (14), (15), (15), (16), (17), (18), (19), (20), (21), (22) and (23), correspondingly.

We can discuss now (on 22 October, 2017) only partially (for the range from 9 August, 2017 to 22 October, 2017) the confirmed validity of the predicted (on 9 August, 2017) probabilities (13) - (23) (based on the established global prediction thermohydrogravidynamic principle (8)) concerning the strongest intensifications of the seismotectonic and climatic processes in California during the predicted ranges (26) - (36).

Table 5 presents the analysis for $2017(\mathrm{~m}=13)$ of the previous significant (according to the U.S. Geological Survey) earthquakes occurred in California (from August 9, 2017 to October 22, 2017) on dates $t_{e}$ near the calculated date $t^{*}\left(\tau_{c, r}, 2017\right)=2017.85$ corresponding to the maximal (in 2017) combined planetary and solar integral energy gravitational influence (8) on the internal rigid core $\tau_{c, r}$ of the Earth. We have also the additional (in addition to Table 5) unquestionable fact [25] (published by Laura Sussman on August 22, 2017) that the moderate 3.2-magnitude earthquake struck on August 22, 2017 "near San Francisco" [25] "right along the San Andreas Fault Line" [25] "according to United States Geological Survey" [25]. Taking into account the date $t_{e}$ (August 22, $2017=2017.64356$ ) of this earthquake, we have that this earthquake struck "near San Francisco" [25] near 75.4 days before the date $\mathrm{t}^{*}\left(\tau_{\mathrm{c}, \mathrm{r}}, 2017\right)=2017.85$ of the local maximum (8) for 2017. We have also the second unquestionable fact that the date $t_{e}$ (August 22, $2017=2017.64356$ ) of this 3.2-magnitude earthquake belongs to the predicted (on 9 August, 2017) range (9 August $\div 7$ November, 2017) (given by (31)) characterized by the probability $\operatorname{Pr}=0.6153$ (given by (18)) of the strongest (in California) earthquakes and related $[4,7-12,14]$ strongest climatic processes near the numerical time moment $\mathrm{t}^{*}\left(\tau_{c, r}, 2017\right)=2017.85$ corresponding approximately to 7 November.

Table 5: The analysis for $2017(\mathrm{~m}=13)$ of the previous significant (according to the U.S.

Geological Survey) earthquakes occurred in California (since August 9, 2017 and before

October 22, 2017) on dates $t_{e}$ near the calculated date $t^{*}\left(\tau_{c, r}, 2017\right)=2017.85$ corresponding to the maximal (in 2017) combined planetary and solar integral energy gravitational influence (8) on the internal rigid core $\tau_{c, r}$ of the Earth.

\begin{tabular}{|c|c|c|c|}
\hline $\begin{array}{c}\text { Magnitude M, } \\
\text { Region }\end{array}$ & $\begin{array}{c}\text { Date } \mathrm{t}_{\mathrm{e}} \text { of } \\
\text { earthquake, in } \mathrm{yr}\end{array}$ & $\begin{array}{c}\text { Date } \\
\mathrm{t}^{*}\left(\tau_{\mathrm{c}, \mathrm{r}}, 2017\right)= \\
2017.85 \text { of the local } \\
\text { maximum (8) for } \\
2017, \text { in yr }\end{array}$ & $\begin{array}{c}\Delta=\mid \mathrm{t}_{\mathrm{e}}-\mathrm{t}^{*}\left(\tau_{\mathrm{c}, \mathrm{r}}, 2017\right) \\
\text { in days }\end{array}$ \\
\hline $\begin{array}{c}\mathrm{M}=\mathbf{4 . 1}, 14 \mathrm{~km} \text { ESE } \\
\text { of Alum Rock, }\end{array}$ & $\begin{array}{c}\text { October 10,2017 } \\
=2017.77737\end{array}$ & 2017.85 & 26.52 days before the \\
\hline
\end{tabular}


DOI: 10.5281/zenodo.1040246

\begin{tabular}{|c|c|c|c|}
\hline California & & date $\mathrm{t}^{*}\left(\tau_{\mathrm{c}, \mathrm{r}}, 2017\right)$ \\
\hline $\begin{array}{c}\mathrm{M}=3.6,5 \mathrm{~km} \mathrm{NW} \text { of } \\
\text { Westwood, CA }\end{array}$ & $\begin{array}{c}\text { September 19,2017 } \\
=2017.71868\end{array}$ & 2017.85 & $\begin{array}{c}47.96 \text { days before the } \\
\text { date } \mathrm{t}^{*}\left(\tau_{\mathrm{c}, \mathrm{r}}, 2017\right)\end{array}$ \\
\hline $\begin{array}{c}\mathrm{M}=3.3,3 \mathrm{~km} \text { NNE of } \\
\begin{array}{c}\text { East Foothills, } \\
\text { California }\end{array}\end{array}$ & $\begin{array}{c}\text { September 15,2017 } \\
=2017.70773\end{array}$ & 2017.85 & $\begin{array}{c}51.96 \text { days before the } \\
\text { date } \mathrm{t}^{*}\left(\tau_{\mathrm{c}, \mathrm{r}}, 2017\right)\end{array}$ \\
\hline
\end{tabular}

Considering (on 22 October, 2017 based on Table 5) the significant earthquakes in California (according to the U.S. Geological Survey) in 2017 (from August 9, 2017 to October 22, 2017), we have the third unquestionable fact that the date (September 15, 2017) of the 3.3-magnitude earthquake (which struck $3 \mathrm{~km}$ NNE of East Foothills, California near 51.96 days before the date $\mathrm{t}^{*}\left(\tau_{\mathrm{c}, \mathrm{r}}, 2017\right)=2017.85$ ) belongs to the predicted (on 9 August, 2017) range (9 August $\div 7$ November, 2017) (given by (31)) characterized by the probability $\operatorname{Pr}=0.6153$ (given by (18)) of the strongest (in California) earthquakes and related [4, 7-12, 14] strongest climatic processes near the numerical time moment $t^{*}\left(\tau_{c, r}, 2017\right)=2017.85$ corresponding approximately to 7 November.

Considering (on 22 October, 2017 based on Table 5) the significant earthquakes in California (according to the U.S. Geological Survey) in 2017 (from August 9, 2017 to October 22, 2017), we have the fourth unquestionable fact that the date (September 19) of the 3.6-magnitude earthquake (which struck $5 \mathrm{~km} \mathrm{NW}$ of Westwood, CA near 47.96 days before the date $\mathrm{t}^{*}\left(\tau_{\mathrm{c}, \mathrm{r}}, 2017\right)=2017.85$ ) belongs to the predicted (on 9 August, 2017) range (17 September $\div 7$ November, 2017) (given by (30)) characterized by the probability $\operatorname{Pr}=0.5384$ (given by (17)) of the strongest (in California) earthquakes and related [4, 7-12, 14] strongest climatic processes near the numerical time moment $\mathrm{t}^{*}\left(\tau_{\mathrm{c}, \mathrm{r}}, 2017\right)=2017.85$ corresponding approximately to 7 November.

Considering (on 22 October, 2017 based on Table 5) the significant earthquakes in California (according to the U.S. Geological Survey) in 2017 (from August 9, 2017 to October 22, 2017), we have the fifth unquestionable fact that the date (October 10, 2017) of the 4.1-magnitude (strongest in California since August 9, 2017 and before October 22, 2017 according to the U.S. Geological Survey) earthquake (which struck 14 km ESE of Alum Rock, California near 26.52 days before the date $t^{*}\left(\tau_{c, r}, 2017\right)=2017.85$ ) belongs to the predicted (on 9 August, 2017) range (7 October $\div 7$ November, 2017) (given by (28)) characterized by the probability $\operatorname{Pr}=0.3846$ (given by (15)) of the strongest (in California) earthquakes and related $[4,7-12,14]$ strongest climatic processes near the numerical time moment $\mathrm{t}^{*}\left(\tau_{\mathrm{c}, \mathrm{r}}, 2017\right)=2017.85$ corresponding approximately to 7 November.

We see that the strongest (in California since August 9, 2017 and before October 22, 2017 according to the U.S. Geological Survey) 4.1-magnitude earthquake (which struck on October 10, 2017) occurred (14 km ESE of Alum Rock, California) for the minimal 26.52 days (as it is 
evident based on the Table 5) before the date $t^{*}\left(\tau_{c, r}, 2017\right)=2017.85$. The considered (on 22 October, 2017) above facts (from the first unquestionable fact to the fifth one) confirm (partially, for the considered above range from August 9, 2017 to October 22, 2017) the validity of the established [8, 10-12] global prediction thermohydrogravidynamic principle (8) for prediction of the strongest intensifications of the seismotectonic processes in California for 2017 during the predicted ranges $(26)-(36)$.

We have the sixth unquestionable fact [26] (published on October 12, 2017) about "at least 17 wildfires in north California" [26] "as seen from space" [26] on October 9, 2017 "by NASA satellites" [26]. We see that the date (October 9, 2017) of the observed "at least 17 wildfires in north California" [26] is in nearly perfect agreement with the date (October 10, 2017) of the strongest (in California since August 9, 2017 and before October 22, 2017 according to the U.S. Geological Survey) 4.1-magnitude earthquake occurred (14 km ESE of Alum Rock, California) for the minimal 26.52 days before the date $\mathrm{t}^{*}\left(\tau_{\mathrm{c}, \mathrm{r}}, 2017\right)=2017.85$.

We have the seventh unquestionable fact that the date (October 9, 2017) ) of the observed "at least 17 wildfires in north California" [26] belongs to the predicted (on 9 August, 2017) range (7 October $\div 7$ November, 2017) (given by (28)) characterized by the probability $\operatorname{Pr}=0.3846$ (given by (15)) of the strongest (in California) earthquakes and related [4, 7-12, 14] strongest climatic processes near the numerical time moment $\mathrm{t}^{*}\left(\tau_{\mathrm{c}, \mathrm{r}}, 2017\right)=2017.85$ corresponding approximately to 7 November.

\section{Conclusions}

We have presented in Section 2 (Methodology) the established [2-4, 7-12, 18] generalized formulation (1) and of the first law of thermodynamics (for the individual finite continuum region $\tau$ (considered in the Galilean frame of reference) subjected to the cosmic and terrestrial non-stationary Newtonian gravitational field and non-potential terrestrial stress forces characterized by the symmetric stress tensor $\mathbf{T}$ [19]) and the established [8, 10-12] global prediction thermohydrogravidynamic principles (8) and (9) (formulated for for the internal rigid core $\tau_{\mathrm{c}, \mathrm{r}}$ of the Earth) determining the maximal temporal intensifications of the global and regional natural (seismotectonic, volcanic, climatic and magnetic) processes of the Earth.

We have shown (based on the considered Table 1, Table 2, Table 3 and Table 4) in Section 3 (Findings) the practical applicability (discussed in Section 4) of the established [8, 10-12] global prediction thermohydrogravidynamic principle (8) for the reasonable explanations of the strongest seismotectonic activity in California (for $2004(\mathrm{~m}=0), 2009(\mathrm{~m}=5), 2013(\mathrm{~m}=9)$ and $2016(\mathrm{~m}=12)$, respectively) near the calculated dates $\left(\mathrm{t}^{*}\left(\tau_{\mathrm{c}, \mathrm{r}}, 2004\right)=2004.6833\right.$, $\left.\mathrm{t}^{*}\left(\tau_{\mathrm{c}, \mathrm{r}}, 2009\right)=2009.05\right), \quad \mathrm{t}^{*}\left(\tau_{\mathrm{c}, \mathrm{r}}, 2013\right)=2013.4666 \quad$ and $\quad \mathrm{t}^{*}\left(\tau_{\mathrm{c}, \mathrm{r}}, 2016\right)=2016.7666$, respectively) corresponding to the maximal (in 2004, in 2009, in 2013 and in 2016, respectively) combined planetary and solar integral energy gravitational influences (8) (for the real planetary configurations during the range $(2004 \div 2016))$ on the internal rigid core $\tau_{c, r}$ of the Earth. 
Based on the established [8, 10-12] and confirmed (in Section 3) global prediction thermohydrogravidynamic principle (8) of the cosmic seismology [8, 10-12], we have founded (on 9 August, 2017 in Section 3 for the real planetary configurations during the range (2004 $\div 2017)$ ) the ranges (24), (25), (26), (27), (28), (29), (30), (31), (32), (33), (34), (35) and (36) of the dates $\mathrm{t}_{\mathrm{e}, \max , 2017}$ and $\mathrm{t}_{\mathrm{e}, \max , 2017-2018}$ of the forthcoming strongest Californian earthquakes (and related [4, 7-12, 14] strongest climatic processes in California determined by the maximal combined planetary and solar integral energy gravitational influence (8) on the internal rigid core $\tau_{\mathrm{c}, \mathrm{r}}$ of the Earth in 2017 near the numerical time moment $\mathrm{t}^{*}\left(\tau_{\mathrm{c}, \mathrm{r}}, 2017\right)=2017.85$ corresponding approximately to 7 November, 2017) characterized by the probabilities (11), (12), (13), (14), (15), (15), (16), (17), (18), (19), (20), (21), (22) and (23), correspondingly.

We have presented (on 22 October, 2017) in Section 4 (Discussions) the confirmed validity (partially, for the range from 9 August, 2017 to 22 October, 2017) of the predicted (on 9 August, 2017) probabilities (13) - (23) (based on the established [8, 10-12] global prediction thermohydrogravidynamic principle (8)) of the strongest intensifications of the seismotectonic and climatic (related with catastrophic wildfires in north California [26]) processes in California during the predicted ranges (26) - (36).

The considered (on 22 October, 2017 in Section 4 ) facts (from the first unquestionable fact to the seventh one) confirm (partially, for the considered range from August 9, 2017 to October 22, 2017) the validity of the established [8, 10-12] global prediction thermohydrogravidynamic principle (8) for prediction of the strongest intensifications of the seismotectonic and climatic (related with catastrophic wildfires in north California [26]) processes in California during the predicted ranges $(26)-(36)$.

\section{Acknowledgements}

The author thanks the Editor in Chief Ms. Tina Sethiya Porwal with gratitude for the editorial comments and corrections improving the final text of the article. The author thanks Mr. A.G. Starikov, Mr. P.E. Shsherbinin and Mrs. O.A. Pavlova for the very constructive discussions.

\section{References}

[1] Charles Francis Richter. (1958). "Elementary Seismology." San Francisco, USA: W.H. Freeman.

[2] Sergey Victorovich Simonenko. (2013). "Fundamentals Of The Thermohydrogravidynamic Theory Of The Global Seismotectonic Activity Of The Earth." International Journal of Geophysics, 2013 (519829), 1-39. http://dx.doi.org/10.1155/2013/519829.

[3] Sergey Victorovich Simonenko. (2014). "The Practical Forecasting Aspects Of The Thermohydrogravidynamic Theory Of The Global Seismotectonic Activity Of The Earth Concerning To The Japanese Earthquakes Near The Tokyo Region." American Journal of Earth Sciences, 1(2), 38-61. http://www.openscienceonline.com/journal/archive2?.journalId=715\&paperId=457.

[4] Sergey Victorovich Simonenko. (2014). "The Linkage Of The Different Distinct Great Volcanic Eruptions Of The Thera (Santorini) In The Range $(1700 \div 1450 \pm 14)$ BC And The Related Subsequent Intensifications Of The Global Seismicity And Volcanic Activity In The End Of The 
19th Century And In The Beginning Of The 20th Century, In The End Of The 20th Century, And In The Beginning Of The 21 st Century AD.” Journal of Advances in Physics, 4(2), 484-516. http://cirworld.org/journals/index.php/jap/article/view/53N.

[5] T. Simkin, L. Siebert, L. McClelland, D. Bridge, C. Newhall, and J. Latter. (1981). "Volcanoes Of The World." Stroudsburg: Hutchinson Ross.

[6] Hubert Horace Lamb. (1977). "Climate: Present, Past And Future. Vol. 2: Climatic History And The Future." London, UK: Methuen.

[7] Sergey Victorovich Simonenko. (2007). "Thermohydrogravidynamics Of The Solar System." Nakhodka, Russia: Institute of Technology and Business Press.

[8] Sergey Victorovich Simonenko. (2012). "The Cosmic Energy Gravitational Genesis Of The Increase Of The Seismic And Volcanic Activity Of The Earth In The Beginning Of The 21st Century AD." Nakhodka, Russia: Institute of Technology and Business Press.

[9] Sergey Victorovich Simonenko. (2015). "The Cosmic Energy Gravitational Genesis Of The Forthcoming Intensifications Of The Global Seismotectonic, Volcanic, Climatic And Magnetic Activities Since 2016 AD." American Journal of Earth Sciences. 2(6), 211-229.

[10] Sergey Victorovich Simonenko. (2014). "The Prognosticating Aspects Of The Developed Cosmic Geophysics Concerning The Subsequent Forthcoming Intensifications Of The Global Seismicity, Volcanic And Climatic Activity Of The Earth In The 21st Century." British Journal of Applied Science \& Technology, 4(25), 3563-3630.

[11] Sergey Victorovich Simonenko. (2016). "The Confirmed Validity Of The Thermohydrogravidynamic Theory Concerning The Strongest Intensifications Of The Global Natural Processes Of The Earth In 2016 Since 1 September, 2016.” British Journal of Applied Science \& Technology, 18(5), 1-20. Article no.BJAST.30049. http://www.journalrepository.org/media/journals/BJAST_5/2017/Jan/Simonenko1852016BJAST 30049.pdf.

[12] Sergey Victorovich Simonenko. (2016). "The Prognosticating Results Of The Cosmic Seismology Concerning The Forthcoming Intensification Of The Global Seismotectonic, Volcanic And Climatic Activities Of The Earth From 1 September To 10 November, 2016 AD." Journal of Advances in Environmental Sciences, 1(2), 90-101.

[13] "Hurricane Matthew is getting stronger." Associated Press. Oct. 6, 2016. AM. http://www.businessinsider.com/hurricane-matthew-getting-stronger-2016-10.

[14] Beno Gutenberg. (1927). Grundlagen der Erdbebenkunde, Germany, Berlin: Gebrüder Bornträger.

[15] Sergey Victorovich Simonenko. (2017). "The Prediction Of The Thermohydrogravidynamic Theory Concerning The Strongest Intensifications Of The Global Natural Processes Of The Earth Since 18 July, 2017 And Before 26 February, 2018." International Journal of Research Granthaalayah. 5(8): 127-145. https://doi.org/10.5281/zenodo.885023.

[16] Frank Bajak. "Damaging Hurricane Harvey Settles In Over Southeast Texas." Associated Press. August 27, 2017. https://www.yahoo.com/news/damaging-hurricane-harvey-settles-oversoutheast-texas-082259260.html.

[17] "Irma grows to dangerous Category 5 hurricane, takes aim at Caribbean islands." WABC - NY. September 6, 2017. https://www.yahoo.com/news/irma-grows-dangerous-category-5115347784.htmlDavid

[18] Sergey Victorovich Simonenko. (2006). "Non-equilibrium Statistical Thermohydrodynamics of Turbulence." Moscow, Russia: Nauka.

[19] Istvan Gyarmati. (1970). "Non-equilibrium Thermodynamics. Field Theory And Variational Principles." Berlin, Germany: Springer-Verlag.

[20] Sybren Ruurds de Groot and Peter Mazur. (1962). "Non-equilibrium Thermodynamics." Amsterdam, Holland: North-Holland Publishing Company.

[21] Josiah Willard Gibbs. (1873). "Graphical Methods In The Thermodynamics Of Fluids." Transactions of the Connecticut Academy, 2, 309-342. 
[22] Lev Davidovich Landau, and Evgeny Mikhailovich Lifshitz. (1976). "Theoretical Physics. Vol. 5. Statistical Physics." Moscow, Russia: Nauka. In Russian.

[23] Sergey Victorovich Simonenko. (2004). "The Macroscopic Non-equilibrium Kinetic Energies Of A Small Fluid Particle.” Journal of Non-Equilibrium Thermodynamics, 29 (2), 107-123.

[24] T. Alboussière, R. Deguen, and M. Melzani. (2010). "Melting-induced Stratification Above The Earth's Inner Core Due To Convective Translation.” Nature, 466, 744-747.

[25] Laura Sussman. "3.2-magnitude earthquake strikes near San Francisco." The Sacramento Bee. August 22, 2017. http://www.sacbee.com/news/state/article168619337.html

[26] Andrea Miller. "Before and after photos of neighborhood destroyed by wildfire in Santa Rosa, California." ABC News. October 12, 2017. http://abcnews.go.com/US/photos-neighborhooddestroyed-wildfire-santa-rosa-california/story?id=50397309

*Corresponding author.

E-mail address: sergeysimonenko@ mail.ru 